\title{
The Short-Term Impact Of Super Bowl Advertising On Stock Prices: An Exploratory Event Study
}

\author{
Jacqueline K. Eastman, Georgia Southern University, USA \\ Rajesh Iyer, Bradley University, USA \\ Joan M. Wiggenhorn, Florida Institute of Technology, USA
}

\begin{abstract}
Advertisers are under pressure to demonstrate the financial effectiveness of their advertising. Event study methodology utilizing measurement and comparison of stock prices may be one way to address this concern. In this study, our results suggest that while advertising in the Super Bowl does not have a significant positive impact on a firm's stock price the day after the Super Bowl, when considering windows from two to four days before and after there is a significant positive stock price effect. Additionally, we found the current method advertisers use to judge the effectiveness of Super Bowl advertising (i.e. likeability with the USA Today poll and Advertising Age poll) had no significant relationship with financial effectiveness as measured by stock price. This suggests that the methods marketers use to judge Super Bowl advertising effectiveness may not be good measures of success in financial terms. Finally, our results suggest that if a firm does choose to advertise in the Super Bowl, they may want to pick the second quarter for their ad and that they need to maximize pre-Super Bowl publicity due to the impact on stock price before the Super Bowl.
\end{abstract}

Keywords: Super Bowl, Advertising, Event Study

\section{INTRODUCTION}

\section{Research Aim}

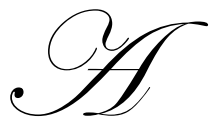

dvertisers have strived to break through audience inattention and this has become even more difficult with the growth of cable television and new media (Chong, Filbeck, and Tompkins, 2007). One impact of this has been the emphasis that advertisers have placed on promoting in major televison events, such as the Super Bowl, the Academy Awards, and show finales (Chong et al., 2007; Filbeck, Zhao, Tompkins, and Chong, 2009).

Additionally, marketers have become increasingly pressured to demonstrate and communicate the economic returns of their strategic decisions (Chong et al., 2007; Delattre, 2007; Filbeck et al., 2009; Srinivasan and Hanssens, 2009; Srinivasan, Pauwels, Silva-Risso, and Hanssens, 2009). Marketers must be able to exhibit the financial return of their advertising strategy (Filbeck et al., 2009) as well as the impact on customers (Rao and Bharadwaj, 2008). Research on the return on investment for marketing expenditures is a priority area for the Marketing Science Institute (Johnston, 2007, 2010; Spais and Fillis, 2008). While marketing initiatives can provide multiple benefits to a firm, "marketing accountability occurs only if these outcomes also ultimately serve to increase the stockholders' wealth (Rao and Bharadwaj, 2008, 16)." Thus, it is becoming more critical for marketers to be able to speak the language of finance to gain support for their marketing activities (McAlister, Srinivasan, and Kim, 2007) and to demonstrate the return on investment for marketing activities (Johnston, 2007). In this paper, we aim to examine this in terms of the impact of Super Bowl advertising on stock prices. 


\section{Reasoning For the Focus Of The Paper}

The Super Bowl is one of the coveted, premier live events for television advertising as many firms spend a large portion of their total advertising budget on this venue (Chong, Filbeck, Tompkins, and Ashman, 2002; Filbeck et al., 2009). Watching the ads during the Super Bowl has become an integral portion of the Super Bowl experience as evidenced by publicity over ads, informal discussions about the ads, and USA Today's Super Bowl Ad Meter (Chong et al., 2007). This is evident through the huge amounts of money advertisers devote to a Super Bowl advertising campaign; a 30-second spot in 2007 was \$2.6 million (Cuneo, 2007b) and climbing. The additional costs to produce a television spot is $\$ 381,000$, on average, though it is significantly higher, a million dollars or more, for Super Bowl ads that utilize celebrities or high end special effects (Horovitz, 2007; Steinberg, 2007). Given that the Super Bowl is the most watched TV program of the year with roughly 90 million viewers in the USA alone (Steinberg, 2007), Super Bowl advertisers see the audience size as worth the expense. While there is anecdotal evidence of the positive impact of Super Bowl advertising, including increased sales, inquiries, and web hits, there is a need for credible measures of return for this investment (Chong et al, 2002).

Several firms make the Super Bowl the cornerstone for their promotional campaign. For example in the 2007 Super Bowl, Anheuser-Busch was the biggest advertiser with five minutes of ad time, nine advertising spots, and a \$25 million dollar investment (Mullman, 2007a). For other firms, their ad(s) in the Super Bowl represent the bulk of their advertising expenditures. For example, Phillips-Van Heusen bought its first Super Bowl ads in 2007 with two 30-second spots (one for Van Heusen brands and one for Izod) (Thompson 2007). Their approximate $\$ 5.2$ million media buy for the Super Bowl compares to their $\$ 2$ million media spending in 2005 and $\$ 700,000$ spent in the first nine months of 2006 (Thompson, 2007).

Thus, given the significant costs involved with Super Bowl advertising, one needs to determine how to measure if the costs are worth it. There is concern that the "vast majority of traditional advertising programs yield disappointing results" (Clancy and Krieg, 2006, p. 28). Many in advertising view a successful Super Bowl ad as one that gets rated in the top twenty ads in the post-Super Bowl ratings, with those ads rated lower than that seen as a failure (Cuneo, 2007a). However, "CEOs and chief financial officers (CFOs), in this age of accountability, demand evidence of marketing's contribution to the bottom line" (Clancy and Krieg, 2006, p. 28). If positive affect and awareness do not translate into return on investment, how can advertisers demonstrate the effectiveness of their efforts?

\section{Previous Research}

Srinivasan and Hanssens (2009) stress how marketing professionals are being challenged to determine the value created by marketing actions and to translate marketing resource allocations to financial performance measures. In their article, they describe a variety of methods and measures of marketing efforts and firm value, including the use of event studies. Rao and Bharadwaj (2008) stress that the link between marketing initiatives and shareholders wealth though is not well understood. McAlister et al. (2007) offer that increasing advertising and Research \& Development expenditures relative to sales can lower a firm's systematic risk. Additionally, Srinivasan et al. (2009) find that investors react favorably to pioneering innovations in a large and growing category, with high perceived quality, backed by substantial advertising support; while, price promotions have a negative impact on stock return due to perceptions of demand weakness.

Spais and Fillis (2008) discuss that research demonstrates that marketing actions impact stock prices. Standard event study methodology has been used in several marketing studies to determine the impact of marketing activities including product innovation, brand extensions, change in names, bad publicity, green marketing, and ecommerce activities (Chong et al., 2002; Filbeck et al, 2009; Srinivasan and Hanssens, 2009) as well as in the management literature (Oler, Harrison, and Allen, 2008). Johnston (2007) classifies 77 marketing research event studies covering a time period from 1980 to mid-2007. While these 77 studies covered a variety of marketing topics, Johnston (2007) categorizing them into three distinct areas: product, promotion, and services. 


\section{Research and Epistemological Approach}

The purpose of this paper is to explore the financial effectiveness of Super Bowl advertising through the use of an exploratory event study to measure the impact on stock prices in the short-term. "Event study methodology is a statistical procedure to examine the effect that the release of information has on the stock market returns of the firm (Chong et al. 2002)" and has been used to measure the direct effects of firm's strategy on stock prices (Chong et al., 2007; Delattre, 2007) in a diversity of fields (Johnston, 2007). It measures the abnormal return for a stock during the course of the event window less the normal expected return, assuming that the event had not taken place (Srinivasan and Hanssens, 2009). "When applied to the measurement of advertising effectiveness, this method is able to capture the abnormal returns of advertising in specific programs, such as the Super Bowl (Filbeck et al., 2009, p. 254)." If it can be demonstrated that Super Bowl advertising can improve a firm's stock price, at least in the short-term, this suggests that Super Bowl advertising is a worthwhile investment and a means for advertisers to demonstrate the effectiveness of their efforts.

Event study methodology holds promise as an effective technique for measuring marketing strategy impact that overcomes issues with other financial measures of marketing's impact. Much of marketing builds value for the intangible assets for the firm, such as brand equity, loyalty, market share, repeat purchase, and customer satisfaction, which is hard to measure as the financial impact of these efforts can be substantially delayed (McAlister et al., 2007; Rao and Bharadwaj, 2008; Srinivasan and Hanssens, 2009). For example, one issue with measuring the impact of advertising on sales and profits is that advertising effects accrue over time (Filbeck et al., 2009). Johnston (2007) notes that the use of event study methodology in marketing will only continue to gain momentum due to increasing demand to demonstrate the financial impact of marketing actions and outlines the key steps and information needed to conduct an event study. Furthermore, Delattre (2007) note that event studies are still under utilized in marketing. Finally, Spais and Fillis (2008) outline the advantages and disadvantages of event study methodology.

It needs to be noted however, that short-window event studies "may not accurately capture the economic impact of complex strategic actions (Oler, Harrison, and Allen 2008; 151)." This can be seen in that the majority of event studies utilize windows within five days of the event (Oler et al., 2008). Oler et al. (2008) describe complex strategic actions as those impacting multiple areas of the firm, such as mergers, alliances, and CEO successions in which a short-window event study may not be appropriate. As our research examines, a significantly less complex, more short-term event, advertising in the Super Bowl, event study methodology is an appropriate research approach.

\section{Originality of Paper and Contribution}

The benefit of this paper is that by doing an event study of the impact of Super Bowl advertising, we can provide guidance to marketers on whether advertising in the Super Bowl does have a positive financial impact and can help managers better allocate scarce resources (Chong et al., 2007). Our study makes a unique contribution by examining one year of Super Bowl advertising in detail, rather than averaging effects over time. Thus, we offer a census of all Super Bowl advertisers in one year. We do this through looking at the impact of Super Bowl advertising on stock prices in a number of areas including stock price both before and after the Super Bowl ads run, stock price relative to several Super Bowl ad favorability rankings, and stock price relative to ad timing in terms of quarter and number of ads run.

\section{LITERATURE REVIEW}

\section{Super Bowl Advertising and its Effectiveness}

When a firm decides to advertise in the Super Bowl there are many things they need to consider. Firms use advertising to accomplish many different goals; these include impacting cognition, affect, and behavior. Firms may choose to advertise to maintain or increase market share and sales or to reverse a decline. For example, with Anheuser-Busch, they are trying to maintain the momentum of Bud Light's increase in sales (with six of their nine Super Bowl spots) while reversing the decline in sales of Budweiser and Budweiser Select (Mullman, 2007a; Horovitz, 2007). In addition, a purpose of Super Bowl advertising is to create a buzz as advertisers struggle to break through the clutter of media choices for consumers. 
The traditional measures to determine the effectiveness of ads is by measuring the familiarity towards the ad, the knowledge about the ad/product depicted in the ad, the frequency and the length of the ad, which all help in measuring the recall of the ad. For example, when viewers are frequently exposed to an ad, they typically have more time to think and elaborate on the message (Cacioppo and Petty, 1979), which helps them to learn and retain information contained within the message (Wu and Newell, 2003).

Previous measures of Super Bowl advertising effectiveness focused on Nielsen numbers and day-after recall, but now measures need to consider online traffic and searches as well as the buzz generated by people talking about the ad (Atkinson, 2007). One well-known measure of Super Bowl advertising is the USA Today's Ad Meter with real-time consumer focus groups rating Super Bowl ads (Horovitz, 2007). The Ad Meter "measures whether 238 people in two states liked the ads" (Mullman, 2007b). In 2007, Anheuser-Busch dominated USA Today's Ad Meter with seven of the top ten ads (Horovitz, 2007) and Anheuser-Busch has won the Ad Meter for the past nine years (Mullman, 2007b).

There is concern though that the use of the Ad Meter exceeds its purpose or methodology (Creamer and Mullman, 2007). The Ad Meter has become the de facto measure of the success of a Super Bowl ad though USA Today itself notes all it measures is whether or not people like the ad, not the effectiveness of the ad (Creamer and Mullman, 2007). Thus, while the Ad Meter does serve a significant purpose in measuring the likeability of Super Bowl ads and offering a source of good publicity, it should not be the sole means to measure the return on investment for Super Bowl advertising (Creamer and Mullman, 2007). It is important that people not just remember the ad and think it is entertaining, but they also need to remember the brand advertised (Rauch, 2001). Finally, it is vital that other means, beyond the Ad Meter, are utilized to determine Super Bowl advertising effectiveness. This study uses the event study methodology to investigate the stock price reactions to Super Bowl advertising.

\section{Event Study Methodology In Marketing}

Event study analysis has been widely accepted as a research tool in the finance and economics discipline and has been also utilized in marketing research. "The value of event studies in marketing is that researchers can estimate the overall financial impact of a particular marketing strategy quickly and empirically (Johnston, 2007, 4; Delattre, 2007)." Chaney, Devinney and Winer (1991) investigate whether stock price changes are associated with new product announcements. Lane and Jacobson (1995) use event study analysis to determine how brand extension announcements impact future assessments of firm value. Jones and Danbolt (2005) find that announcement of product and market diversification efforts lead to significantly abnormal positive returns, particularly in the areas of new products in new markets.

In terms of event studies concerning advertising, Johnston (2007) describes articles dealing with deceptive advertising, news releases, brand images, financial relations advertising, advertising slogan changes, new advertising agency-client relations, advertising agency termination, green marketing, quality achievement awards, diversity, sponsorship and events, and Super Bowl advertising. Agarwal and Kamakura (1995) assess the perceived worth of celebrity endorsers by comparing announcements of such announcements with their associated stock returns. Mathur, Mathur, and Rangan (1997) find that the market-adjusted value for McDonald's of Michael Jordan returning to the NBA is almost two percent. In looking at Australia specifically, Johnston (2010) find sponsorship expenditures to be marginally value enhancing at best and that investors prefer short sponsorship contracts versus a North American preference for longer sponsorship contracts. Spais and Fillis (2006) examine the positive impact of Olympic sponsorship on stock price while Spais and Fillis (2008) note differing stock impacts on sponsorship benefits for the sponsor versus the sponsored organization. Clark, Cornwell, and Pruitt (2009) find that title sponsorships generally trade at market-clearing prices with the exception of NASCAR races with an increase in stock prices. Miyazaki and Morgan (2001) address the valuation aspect of advertising strategies with event study analysis. Kim and Morris (2003) look at the perception of a company's advertising as reflected in the stock price performance at certain peak advertising periods. In all these studies, event study analysis provide practical marketplace measures to assess otherwise difficult-to-assess marketing variables. 


\section{Super Bowl Event Studies}

There have been several studies that looked specifically at the Super Bowl utilizing event study methodology. Fehle, Tsyplakov, and Zdorovtsov (2005) look at Super Bowls leading up to 2001 and find positive abnormal returns for firms advertising in the Super Bowl which they attribute to heavy trading by small investors. Tsai, Chang, and Chen (2005), in looking at Super Bowl ads from 1985 to 2002, find that Super Bowl campaigns do create positive returns and that specifically advertisers with high relative ad expenditures and moderate repetition had effective results. Chang, Jiang, and Kim (2009) looked at Super Bowls from 1989 to 2005 and found that "liked" Super Bowl ads had higher stock returns due to irrational representativeness bias. Kim and Morris (2003), however, in looking at Super Bowls from 1998 to 2000, find a significant, negative cumulative effect, particularly for dotcom firms, and offer that Super Bowl advertising may not be an efficient investment. Additionally, Kim and Morris (2003) do not find a relationship between stock price and either likeability or number of Super Bowl ads.

Chong et al. (2002) look at the impact for ten years of Super Bowl advertising (1990 to 1999) to determine the impact on stock prices for both announcing a firm's intention to advertise on the Super Bowl as well as actually running the Super Bowl ad. Their results suggest that "a firm's announcement to advertise on the Super Bowl is associated with statistically insignificant negative excess returns (Chong et al., 2002, p. 17). This result is explained as announcing that one was doing an ad was no predictor of the probability of the success of the ad as investors had not seen the ad yet (Chong et al., 2002). The day after the Super Bowl, the average reaction is .16 percent positive excess return which is statistically significant at the .05 level; this positive return is similar to that found in other marketing event studies and can be attributed to the market reacting positively to the actual ad execution (Chong et al., 2002). Filbeck et al. (2009), in looking at a summary of Super Bowl ads from 1990 to 2006, found in terms of Super Bowl advertising that firms advertising for the first time on the Super Bowl have greater expenditures relative to sales, and that more effective creative campaigns fare better in terms of market reaction to their ads.

\section{THEORETICAL FRAMEWORK}

The theory underlying the use of event study methodology is the efficient market hypothesis, that a firm's stock price reflects the true value of the firm as they reflect the discounted value of future earnings as well as all relevant information known in the market (Chong et al., 2007, Filbeck et al., 2009). This share price indicates the valuation or consensus forecast of a firm's financial health (Srinivasan and Hanssens, 2009). Per Delattre (2007), an event study allows both the informational content and market efficiency of the event to be tested. As investors interpret marketing activities in determining a firm's value, marketers need to incorporate investor behavior in their actions (Srinivasan and Hanssens, 2009).

Additionally, the use of signaling theory is useful as the announcement and running of Super Bowl ads may constitute signals about the future earnings of the firm that could impact stock price, but the market must evaluate if the cost of the signal justifies the potential benefit (Filbeck et al., 2009). "A central tenet of signaling theory is that the signal must be sufficiently observable and unambiguous to ensure informed participants (i.e. investors) are able to comprehend and exploit the signal successfully (Johnston, 2010, 160)" and that the signal should convey information relevant to the firm's economic performance (Johnston, 2010: Srinivasan and Hanssens, 2009). Event study methodology is frequently used to measure the reaction of financial markets to corporate signaling activity (Johnston, 2010).

Finally, Johnson and Tellis (2005) describe two potential theories for examining stock information on consumer perceptions: the hot hand theory in which investors buy winners and the gambler's fallacy in which they dump losers. However as the time period lengthens, each of these strategies can reverse. Both of these fallacies are a result of investors' misunderstanding of events and their inability to correctly forecast earnings. As our study examines actual stock prices rather than consumers' stock purchase perceptions, these theories would not apply.

The research questions we address are whether or not advertising in the Super Bowl will have a positive impact on stock returns, (will the market reward these firms who advertise in the Super Bowl with positive abnormal returns) before and after the game day? Keeping in mind the question that Oler, Harrison, and Allen (2008) pose considering the proper event window and the fact that Chong et al. (2007) find no significant returns on the 
announcement day concerning a Super Bowl ad, we feel that proper window for computing Super Bowl returns more properly include both before and after the actual event.

Furthermore, as suggested by Kim and Morris (2003), we test if those Super Bowl advertisements that are seen as better, per traditional measures of Super Bowl advertising success, have higher abnormal returns? Finally, we determine if the intensity of Super Bowl advertising (determined by the number of Super Bowl ads placed by the firm) or placement within the Super Bowl (i.e. which quarter are the ads placed) have an impact on stock return.

\section{METHODOLOGY AND DATA MEASUREMENT}

\section{Research Method}

We follow the same methodology as Miyazaki and Morgan (2001) for the event study analysis, operating under the assumption that stock prices reflect investor assessments of the present value of a firm (including discounted future income, expenditures, strategic actions, etc.) We utilize the steps as outlined by Johnston (2007): identify the event of interest, define criteria for inclusion of the event, calculate normal and abnormal returns, estimate the normal performance model, and perform statistical and hypotheses tests utilizing the stock-listed firms, the event dates of interest, and relevant stock prices. The basic event study methodology essentially involves measuring how a certain event influences movement in particular stock prices. In this study, the event in question is the Super Bowl advertising of participating firms. In addition, we follow the advice of Delattre (2007) by performing univariate tests on the abnormal returns using various determinants of advertising "success", number of ads, and the quarter in which the ad appeared. In addition, we use these same independent variables when performing the cross section regressions.

\section{Determination of Ads in the Super Bowl}

To determine what ads appeared on the Super Bowl, the authors utilized three sources: Advertising Age, CBS, and USA Today along with watching a recorded version of the Super Bowl to capture each advertisement. The number of firms that advertised was 31, of which 24 were publicly traded firms and that became the sample. The number of ads, the quarter in which they were shown and the product advertised were noted. ${ }^{1}$

\section{Ad Success Measurement}

Five different ranking methods are used. The first is the USA Today ranking from 1 to 57. This ranking measured likeability by USA Today's viewer poll. The next two rankings use the 1-10 ranking by Advertising Age for the advertisements most liked as well as those most recalled. If an ad is not in the top ten, it is given a score of 11. The fourth method is the list of top ten advertisements that were "Tivoed". This would suggest that ad successfully garnered attention. In this case, a dichotomous variable is used with 1 representing firms in the top ten and 0 for those that were not in the top ten. The final method is we then added up how many of these top ten rankings (TOPTEN) a firm received and those firms that had at least one were considered to have had a successful Super Bowl ad. In this case, the number of times that a firm had any ad in the top ten in the previous categories is counted with the maximum number being 17 for Anheuser-Busch which had a total of 9 ads. All other firms, with no Top Ten rankings, are set equal to 0 .

\section{Stock Price Data and Russell 3000 Index}

Stock price data for each firm was obtained from Yahoo! Finance as was the price for the Russell 3000 Index which is used as a broad market measure. The total assets of each firm for the latest quarter reported in 2006 were primarily obtained from Mergent Online. In the case of foreign firms, total asset data was obtained directly from the Edgar filings.

\footnotetext{
${ }^{1}$ A complete list of firms advertising in the Super Bowl along with the ad ratings and quarter played is available upon request from the authors.
} 
The economy and the stock market were both relatively bullish at the time. Examining the period from June 2006 through June 2007, one finds that the Russell Index began at 745.85 and ended the period at 873.19. Since we are calculating only abnormal returns, the day to day changes in the index will be accounted for. The state of the economy may also be relevant for the impact of advertising on stock prices (Wiggenhorn, Eastman, Iyer, and Armul, Forthcoming; Tellis and Tellis, 2009). Fourth quarter 2006 and first quarter 2007 both exhibited strong growth rates.

\section{STATISTICAL ANALYSIS}

Using the stock price data from Yahoo! Finance, the daily returns for each firm as well as the market index are computed for the five trading days prior to the Super Bowl and the five trading days following the Super Bowl. Per Johnston (2007), the period of interest is the actual day of the event plus the five to ten days immediately surrounding it. The belief is that the "event" will have both a leakage component as well as a continuing reaction for several days following the Super Bowl, but that it is important to have narrow event windows due to the rapid response of stock prices to information and the reduction of noise effects (Delattre, 2007). Thus, the literature supports our choice of dates of interest. Abnormal returns are calculated using the market adjusted method of Brown and Warner (1985) and Cox and Peterson (1994). Hence for each firm, the abnormal return is calculated as the difference between the firm's return and that of the market. The abnormal returns are calculated as:

$A R_{i j}=R_{i j}-M R_{i}$

Where:

$\mathrm{AR}_{\mathrm{ij}}$ is the abnormal return for each firm $\mathrm{j}$ on day $\mathrm{i}$,

$R_{i j}$ is the actual return for each firm $j$ on day $i$, and

$\mathrm{MR}_{\mathrm{i}}$ is the return of the Russell 3000 Index on day i.

For each firm, the Cumulative Abnormal Return $\left(\mathrm{CAR}_{\mathrm{j}}\right)$ for different "windows" is calculated as well as the Average Abnormal Return per day $\left(\mathrm{AAR}_{\mathrm{i}}\right)$, and the Average Cumulative Abnormal Return (ACAR).Thus, the Cumulative Abnormal Return (CAR) is calculated as:

$C A R_{j}=\Sigma A R_{i j}$ for days $i=-5$ to +5

The average abnormal return (AAR) per day is calculated as:

$A A R_{i}=1 / N \Sigma A R_{i j}$ for firm $j=1$ to $N$.

And the average cumulative abnormal return (ACAR) for the $\mathrm{N}$ firms is:

$A C A R=1 / \mathrm{N} \Sigma C A R_{j}$ for firm $j=1$ to $N$.

In addition, once the ACARs are determined, we perform several univariate tests as well as a cross section regression analysis.

\section{RESULTS}

\section{Descriptive Statistics}

The descriptive statistics are presented in Table 1. These include the mean and median as well as the skewness and kurtosis data. These results plus the data from Table 2 show that the market adjusted abnormal returns for individual days are both statistically insignificant and subject to significant skewness and/or kurtosis. However, the 4, 6, and 8 day windows are not subject to either skewness or kurtosis. We believe that unlike some event studies which quite properly should be limited to one or two days (Oler, Harrison, and Allen, 2008), the Super Bowl returns are more properly felt both before and after the event. 
Table 1: Descriptive Statistics

Panel A: Trading Days Before Super Bowl

\begin{tabular}{|l|r|r|r|r|r|}
\hline & \multicolumn{1}{|c|}{ Day -1 } & \multicolumn{1}{c|}{ Day -2 } & \multicolumn{1}{c|}{ Day -3 } & \multicolumn{1}{c|}{ Day -4 } & \multicolumn{1}{c|}{ Day -5 } \\
\hline Mean & $4.294 \mathrm{E}-03$ & $3.113 \mathrm{E}-03$ & $7.852 \mathrm{E}-04$ & $2.939 \mathrm{E}-03$ & $-6.5016 \mathrm{E}-03$ \\
\hline Median & $2.178 \mathrm{E}-03$ & $1.571 \mathrm{E}-03$ & $-1.8921 \mathrm{E}-03$ & $-5.1450 \mathrm{E}-04$ & $-3.3893 \mathrm{E}-03$ \\
\hline Std. Deviation & $1.884 \mathrm{E}-02$ & $1.073 \mathrm{E}-02$ & $9.539 \mathrm{E}-03$ & $1.384 \mathrm{E}-02$ & $2.285 \mathrm{E}-02$ \\
\hline Variance & $3.549 \mathrm{E}-04$ & $1.151 \mathrm{E}-04$ & $9.099 \mathrm{E}-05$ & $1.915 \mathrm{E}-04$ & $5.223 \mathrm{E}-04$ \\
\hline Skewness & 2.070 & .671 & 1.104 & -.193 & -3.109 \\
\hline Std. Error of Skewness & .472 & .472 & .472 & .472 & .472 \\
\hline Kurtosis & 6.989 & .672 & 1.072 & -.776 & .918 \\
\hline Std. Error of Kurtosis & .918 & .918 & .918 & .918 \\
\hline
\end{tabular}

Panel B: Trading Days After Super Bowl

\begin{tabular}{|l|r|r|r|r|r|}
\hline & \multicolumn{1}{|c|}{ Day +1 } & \multicolumn{1}{c|}{ Day +2 } & \multicolumn{1}{c|}{ Day +3 } & \multicolumn{1}{c|}{ Day +4 } & \multicolumn{1}{c|}{ Day +5 } \\
\hline Mean & $1.381 \mathrm{E}-03$ & $2.124 \mathrm{E}-03$ & $3.298 \mathrm{E}-03$ & $-1.9272 \mathrm{E}-03$ & $-2.5546 \mathrm{E}-05$ \\
\hline Median & $2.064 \mathrm{E}-04$ & $5.121 \mathrm{E}-03$ & $6.187 \mathrm{E}-04$ & $-2.9746 \mathrm{E}-03$ & $6.812 \mathrm{E}-04$ \\
\hline Std. Deviation & $7.722 \mathrm{E}-03$ & $1.378 \mathrm{E}-02$ & $1.884 \mathrm{E}-02$ & $1.064 \mathrm{E}-02$ & $1.332 \mathrm{E}-02$ \\
\hline Variance & $5.963 \mathrm{E}-05$ & $1.898 \mathrm{E}-04$ & $3.550 \mathrm{E}-04$ & $1.132 \mathrm{E}-04$ & $1.775 \mathrm{E}-04$ \\
\hline Skewness & .156 & -.708 & 2.180 & .104 \\
\hline Std. Error of Skewness & .472 & .472 & .472 & .058 & .472 \\
\hline Kurtosis & $1.381 \mathrm{E}-03$ & $2.124 \mathrm{E}-03$ & $3.298 \mathrm{E}-03$ & $-1.9272 \mathrm{E}-03$ & $-2.5546 \mathrm{E}-05$ \\
\hline Std. Error of Kurtosis & $2.064 \mathrm{E}-04$ & $5.121 \mathrm{E}-03$ & $6.187 \mathrm{E}-04$ & $-2.9746 \mathrm{E}-03$ & $6.812 \mathrm{E}-04$ \\
\hline
\end{tabular}

Panel C: Windows Before and After Super Bowl

\begin{tabular}{|l|r|r|r|r|r|}
\hline & \multicolumn{1}{|c|}{$\mathbf{W}(+\mathbf{1},+\mathbf{3})$} & \multicolumn{1}{|c|}{$\mathbf{( - 1 , + 1 )}$} & \multicolumn{1}{|c|}{$\mathbf{W}(\mathbf{- 2 , + 2})$} & \multicolumn{1}{|c|}{$\mathbf{W}(\mathbf{- 3 , + 3})$} & $\mathbf{W}(\mathbf{- 4 , + 4 )}$ \\
\hline Mean & $6.804 \mathrm{E}-03$ & $5.676 \mathrm{E}-03$ & $1.091 \mathrm{E}-02$ & $1.500 \mathrm{E}-02$ & $1.601 \mathrm{E}-02$ \\
\hline Median & $1.892 \mathrm{E}-03$ & $5.681 \mathrm{E}-03$ & $1.348 \mathrm{E}-02$ & $1.344 \mathrm{E}-02$ & $9.692 \mathrm{E}-03$ \\
\hline Std. Deviation & $2.186 \mathrm{E}-02$ & $1.904 \mathrm{E}-02$ & $3.004 \mathrm{E}-02$ & $3.699 \mathrm{E}-02$ & $4.035 \mathrm{E}-02$ \\
\hline Variance & $4.777 \mathrm{E}-04$ & $3.625 \mathrm{E}-04$ & $9.026 \mathrm{E}-04$ & $1.368 \mathrm{E}-03$ & $1.628 \mathrm{E}-03$ \\
\hline Skewness & 1.383 & 1.145 & .429 & .805 & .664 \\
\hline Std. Error of Skewness & .472 & .472 & .472 & .472 & .472 \\
\hline Kurtosis & 3.698 & 4.277 & 1.132 & .969 & .243 \\
\hline Std. Error of Kurtosis & .918 & .918 & .918 & .918 & \\
\hline
\end{tabular}

Table 2: Abnormal Returns

This table shows the abnormal returns as well as the significance level for the week before the Super Bowl, the week following the Super Bowl and the CARs for various windows of time with Super Bowl Day designated as Day 0. Number in parenthesis is the $t$ statistic and * denotes significance.

Panel A: Pre Super Bowl Period

\begin{tabular}{|c|c|c|c|c|}
\hline Day -1 & Day -2 & Day -3 & Day -4 & Day -5 \\
\hline $\begin{array}{l}0.43 \% \\
(1.18)\end{array}$ & $\begin{array}{l}0.31 \% \\
(1.42)\end{array}$ & $\begin{array}{l}0.08 \% \\
(0.41)\end{array}$ & $\begin{array}{l}0.29 \% \\
(1.04)\end{array}$ & $\begin{array}{l}-0.65 \% \\
(-1.39)\end{array}$ \\
\hline \multicolumn{5}{|c|}{ Panel B: Post Super Bowl Period } \\
\hline Day +1 & Day +2 & Day +3 & Day +4 & Day +5 \\
\hline $\begin{array}{l}0.14 \% \\
(0.88)\end{array}$ & $\begin{array}{l}0.21 \% \\
(0.76)\end{array}$ & $\begin{array}{l}0.33 \% \\
(0.86)\end{array}$ & $\begin{array}{l}-0.19 \% \\
(-0.89)\end{array}$ & $\begin{array}{l}-0.00 \% \\
(-0.00)\end{array}$ \\
\hline \multicolumn{5}{|c|}{ Panel C: CARs for Different Windows } \\
\hline$(+1,+3)$ & $(-1,+1)$ & $(-2,+2)$ & $(-3,+3)$ & $(-4,+4)$ \\
\hline $\begin{array}{l}0.68 \% \\
(1.53)\end{array}$ & $\begin{array}{l}0.57 \% \\
(1.46)\end{array}$ & $\begin{array}{c}1.09 \% \\
(1.78)^{*}\end{array}$ & $\begin{array}{l}1.50 \% \\
(1.99)^{*}\end{array}$ & $\begin{array}{l}1.60 \% \\
(1.94)^{*}\end{array}$ \\
\hline
\end{tabular}

$*$ significant at $.10 * *$ significant at $.05 * * *$ significant at .01 


\section{Abnormal Returns}

The market-adjusted abnormal returns are found in Table 2. The abnormal returns are positive but not significant for all days except Days $-4,-5$ and +5 when the abnormal returns are negative but not significant. We do find significant positive returns for the three windows $(-2,+2),(-3,+3)$, and $(-4,+4)$. This implies that the talk about the ads before they are even shown has an impact and that this impact continues to affect stock prices several days after the Super Bowl. In addition, as discussed above, the mean and median are both similar and there is no significant skewness or kurtosis. Since we use the $(-3,+3)$ window in most of the cross section regressions, we provide a histogram for the ACARs in Figure 1.

Figure 1. Histogram Average Cumulative Abnormal Returns For Window $(-3,+3)$

\section{M3TOP3}

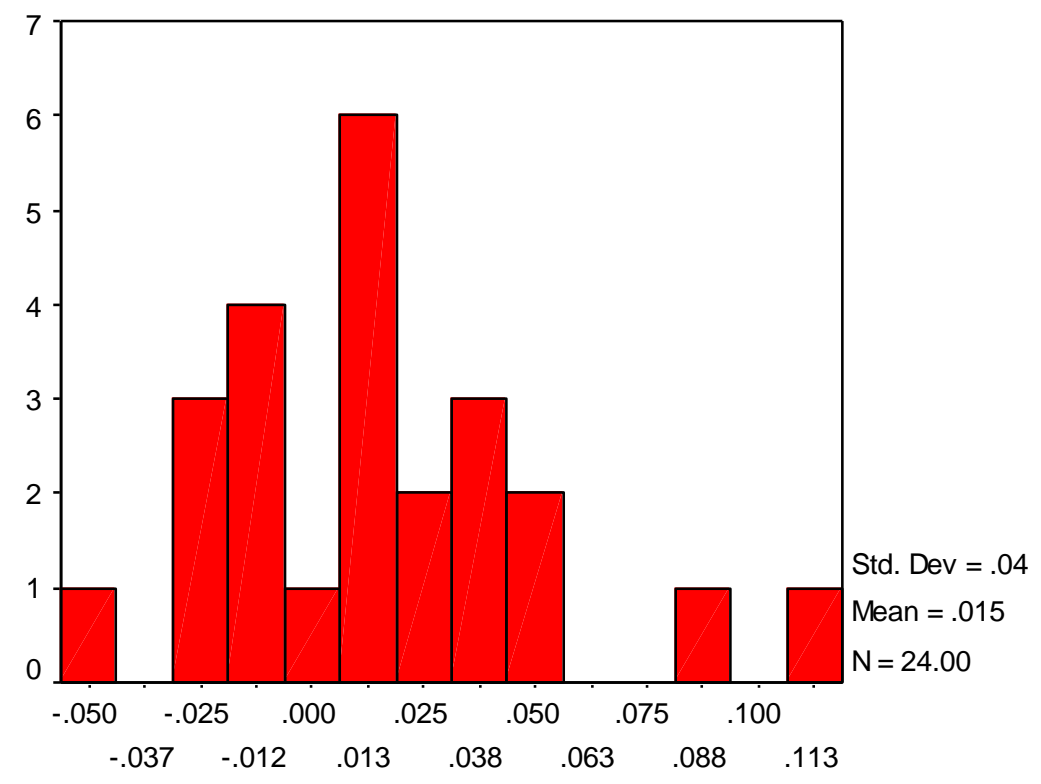

M3TOP3

\section{Impact of Ad Rankings}

We next examine the impact of ad rankings on abnormal returns as shown in Table 3 . The results are somewhat surprising. For the USA TODAY rankings, while the more highly rated do have higher returns the day after the Super Bowl, the difference is not significant. Surprisingly, those firms that are most highly rated, have significantly lower returns for the two day post Super Bowl window and the $(-3,+3)$ and $(-4$, +4) windows. The liked rankings for Ad Age has similar results for both the first day and the longer windows with the first day returns being significantly higher while the longer windows are significantly lower. The ADAGE recall results are not significant, probably due to the extremely small sample size for the firms whose ads were highly ranked. The top groupings for both the TIVO variable and the TOPTEN variable have significantly higher returns for the shorter ( -1 , +1 ) window but the longer windows are once again negative although the differences are not significant. 
Table 3: Effect Rating Level on Cumulative Abnormal Returns

This table presents the market adjusted CARs depending on the rating/ranking of the Super Bowl ad. There are five different ratings regimes to consider. The CARs for those in the higher bracket and the lower bracket are both presented in Panel A. Panel $\mathrm{B}$ shows the results of the test for equality of means. The $\mathrm{t}$ statistics are shown in parenthesis and * denotes significance.

Panel A:

\begin{tabular}{|c|c|c|c|c|c|c|c|}
\hline Days & $(+1)$ & $(+1,+3)$ & $(+1,+4)$ & $(-1,+1)$ & $(-2,+2)$ & $(-3,+3)$ & $(-4,+4)$ \\
\hline $\begin{array}{l}\text { USA Today }<23 \\
12 \text { firms }\end{array}$ & $\begin{array}{l}0.33 \% \\
(1.30) \\
\end{array}$ & $\begin{array}{l}-0.22 \% \\
(-0.43) \\
\end{array}$ & $\begin{array}{l}-0.15 \% \\
(-0.30) \\
\end{array}$ & $\begin{array}{l}0.78 \% \\
(1.21) \\
\end{array}$ & $\begin{array}{l}0.21 \% \\
(0.20) \\
\end{array}$ & $\begin{array}{r}-0.08 \% \\
(-0.08) \\
\end{array}$ & $\begin{array}{l}0.21 \% \\
(0.18) \\
\end{array}$ \\
\hline $\begin{array}{l}\text { USA Today }>=23 \\
12 \text { firms }\end{array}$ & $\begin{array}{l}-0.06 \% \\
(-0.32)\end{array}$ & $\begin{array}{c}1.58 \% \\
(2.42)^{* *}\end{array}$ & $\begin{array}{l}1.12 \% \\
(1.58)\end{array}$ & $\begin{array}{l}0.35 \% \\
(0.78)\end{array}$ & $\begin{array}{c}1.97 \% \\
(3.37)^{* * *}\end{array}$ & $\begin{array}{c}3.08 \% \\
(3.32) * * *\end{array}$ & $\begin{array}{c}2.99 \% \\
(2.77) * *\end{array}$ \\
\hline $\begin{array}{l}\text { Ad Age } \\
\text { Top } 10 \text { liked } \\
4 \text { firms } \\
\end{array}$ & $\begin{array}{l}0.79 \% \\
(1.75)\end{array}$ & $\begin{array}{r}-0.43 \% \\
(-0.44)\end{array}$ & $\begin{array}{l}0.21 \% \\
(0.22)\end{array}$ & $\begin{array}{l}0.85 \% \\
(1.73)\end{array}$ & $\begin{array}{l}-0.36 \% \\
(-0.24)\end{array}$ & $\begin{array}{r}-1.45 \% \\
(-1.00)\end{array}$ & $\begin{array}{l}-0.96 \% \\
(-0.81)\end{array}$ \\
\hline $\begin{array}{l}\text { Ad Age } \\
\text { Not top } 10 \text { liked } \\
20 \text { firms }\end{array}$ & $\begin{array}{l}0.01 \% \\
(0.05)\end{array}$ & $\begin{array}{l}0.90 \% \\
(1.82)^{*}\end{array}$ & $\begin{array}{l}0.54 \% \\
(1.08)\end{array}$ & $\begin{array}{l}0.51 \% \\
(1.11)\end{array}$ & $\begin{array}{l}1.38 \% \\
(2.05)^{*}\end{array}$ & $\begin{array}{l}2.09 \% \\
(2.59) * *\end{array}$ & $\begin{array}{l}2.11 \% \\
(2.28)^{* *}\end{array}$ \\
\hline $\begin{array}{l}\text { Ad Age } \\
\text { Top Ten Recalled } \\
2 \text { firms } \\
\end{array}$ & $\begin{array}{l}0.01 \% \\
(1.26)\end{array}$ & $\begin{array}{l}-1.45 \% \\
(-2.35)\end{array}$ & $\begin{array}{l}0.58 \% \\
(0.37)\end{array}$ & $\begin{array}{l}1.10 \% \\
(1.75)\end{array}$ & $\begin{array}{l}-0.21 \% \\
(-0.63)\end{array}$ & $\begin{array}{l}-1.54 \% \\
(-2.29)\end{array}$ & $\begin{array}{l}-0.43 \% \\
(-0.29)\end{array}$ \\
\hline $\begin{array}{l}\text { Ad Age } \\
\text { Not top ten Recalled } \\
22 \text { firms }\end{array}$ & $\begin{array}{c}0.15 \% \\
(.87)\end{array}$ & $\begin{array}{l}0.87 \% \\
(1.89)^{*}\end{array}$ & $\begin{array}{l}0.48 \% \\
(1.02)\end{array}$ & $\begin{array}{l}0.52 \% \\
(1.23)\end{array}$ & $\begin{array}{l}1.21 \% \\
(1.82)^{*}\end{array}$ & $\begin{array}{l}1.78 \% \\
(2.23)^{* *}\end{array}$ & $\begin{array}{l}1.79 \% \\
(2.02)^{*}\end{array}$ \\
\hline $\begin{array}{l}\text { Tivo Top Ten } \\
6 \text { firms } \\
\end{array}$ & $\begin{array}{l}0.43 \% \\
(1.27) \\
\end{array}$ & $\begin{array}{l}0.15 \% \\
(0.21) \\
\end{array}$ & $\begin{array}{l}0.53 \% \\
(0.79) \\
\end{array}$ & $\begin{array}{l}1.68 \% \\
(1.59) \\
\end{array}$ & $\begin{array}{l}0.84 \% \\
(0.47) \\
\end{array}$ & $\begin{array}{l}0.65 \% \\
(0.33) \\
\end{array}$ & $\begin{array}{l}1.46 \% \\
(0.70) \\
\end{array}$ \\
\hline $\begin{array}{l}\text { Tivo Not Top Ten } \\
18 \text { firms } \\
\end{array}$ & $\begin{array}{l}0.04 \% \\
(0.22) \\
\end{array}$ & $\begin{array}{l}0.86 \% \\
(1.56) \\
\end{array}$ & $\begin{array}{l}0.47 \% \\
(0.86) \\
\end{array}$ & $\begin{array}{l}0.20 \% \\
(0.54) \\
\end{array}$ & $\begin{array}{l}1.18 \% \\
(1.95) * \\
\end{array}$ & $\begin{array}{l}1.78 \% \\
(2.23) * * \\
\end{array}$ & $\begin{array}{l}1.65 \% \\
(1.85 *) \\
\end{array}$ \\
\hline $\begin{array}{l}\text { Overall One of Top Ten } \\
7 \text { firms }\end{array}$ & $\begin{array}{l}0.58 \% \\
(1.79) \\
\end{array}$ & $\begin{array}{l}0.47 \% \\
(0.68) \\
\end{array}$ & $\begin{array}{l}0.67 \% \\
(1.15) \\
\end{array}$ & $\begin{array}{l}1.67 \% \\
(1.87) \\
\end{array}$ & $\begin{array}{l}1.16 \% \\
(0.75) \\
\end{array}$ & $\begin{array}{l}0.86 \% \\
(0.52) \\
\end{array}$ & $\begin{array}{l}1.38 \% \\
(0.78) \\
\end{array}$ \\
\hline $\begin{array}{l}\text { Overall Not Top Ten } \\
17 \text { firms }\end{array}$ & $\begin{array}{r}-0.04 \% \\
(-0.17) \\
\end{array}$ & $\begin{array}{l}0.77 \% \\
(1.34) \\
\end{array}$ & $\begin{array}{l}0.41 \% \\
(0.71) \\
\end{array}$ & $\begin{array}{l}0.11 \% \\
(0.31) \\
\end{array}$ & $\begin{array}{l}1.06 \% \\
(1.67) \\
\end{array}$ & $\begin{array}{l}1.76 \% \\
(2.08)^{*} \\
\end{array}$ & $\begin{array}{l}1.69 \% \\
(1.79)^{*} \\
\end{array}$ \\
\hline
\end{tabular}

Panel B: Difference Between The Means Tests

\begin{tabular}{|c|c|c|c|c|c|}
\hline Days & $\begin{array}{c}\text { USA TODAY } \\
<23 \text { vs. }>=23\end{array}$ & $\begin{array}{c}\text { AD AGE } \\
\text { Top Ten Like vs. Not } \\
\text { Top Ten Like }\end{array}$ & $\begin{array}{c}\text { AD AGE } \\
\text { Top Ten Recall vs. } \\
\text { Not Top Ten Recall }\end{array}$ & $\begin{array}{c}\text { TIVO } \\
\text { Top Ten vs. } \\
\text { Not Top Ten }\end{array}$ & $\begin{array}{c}\text { OVERALL } \\
\text { Top Ten vs. } \\
\text { Not Top Ten }\end{array}$ \\
\hline$(+1)$ & $(1.25)$ & $(1.97)^{*}$ & $(-0.23)$ & $(1.09)$ & $(1.87)^{*}$ \\
\hline$(+1,+3)$ & $(-2.18)^{* *}$ & $(-1.11)$ & $(-1.48)$ & $(-0.68)$ & $(-0.30)$ \\
\hline$(-1,+1)$ & $(0.53)$ & $(0.32)$ & $(0.40)$ & $(1.73)^{*}$ & $(1.92)^{*}$ \\
\hline$(-3,+3)$ & $(-2.28)^{* *}$ & $(-1.84)^{*}$ & $(-1.23)$ & $(-0.64)$ & $(-0.54)$ \\
\hline$(-4,+4)$ & $(-1.77)^{*}$ & $(-1.42)$ & $(-0.74)$ & $(-0.10)$ & $(-0.17)$ \\
\hline
\end{tabular}

*significant at $.10 * *$ significant at $.05 * * *$ significant at .01

\section{Impact of Ad Timing and Number of Ads}

Next the impact of how the quarter that a firm's first ad was shown is examined. As can be seen in Table 4, firms whose ads were first shown in the second quarter perform better than any other quarter. Also, firms that had only one ad perform better the first day following the Super Bowl and for the longer windows, although the differences are not significant. 
Table 4: Effect Quarter Ad Shown and Number of Ads on Cumulative Abnormal Returns

This table presents the market adjusted CARs depending on the first quarter that a firm had a Super Bowl ad. This table also shows the CARs for firms that had only one ad and those that had multiple ads. The CARs presented in Panel A. Panel B shows the results of the test for equality of means. The $t$ statistics are shown in parenthesis and $*$ denotes significance.

Panel A:

\begin{tabular}{|l|c|c|c|c|c|c|c|}
\hline Days & $(+1)$ & $(+1,+3)$ & $(+1,+4)$ & $(-1,+1)$ & $(-2,+2)$ & $(-3,+3)$ & $(-4,+4)$ \\
\hline First Quarter & $0.19 \%$ & $0.37 \%$ & $0.53 \%$ & $1.29 \%$ & $1.00 \%$ & $1.16 \%$ & $1.80 \%$ \\
9 firms & $(0.69)$ & $(0.72)$ & $(1.05)$ & $(1.78)$ & $(0.86)$ & $(0.87)$ & $(1.14)$ \\
\hline Second Quarter & $0.05 \%$ & $2.71 \%$ & $2.25 \%$ & $0.38 \%$ & $2.76 \%$ & $4.04 \%$ & $3.77 \%$ \\
6 firms & $(0.15)$ & $(2.49)^{*}$ & $(2.06)^{*}$ & $(0.46)$ & $(2.51)^{*}$ & $(2.36)^{*}$ & $(2.18)^{*}$ \\
\hline Third Quarter & $0.26 \%$ & $-0.44 \%$ & $-0.89 \%$ & $0.07 \%$ & $-0.04 \%$ & $0.06 \%$ & $0.11 \%$ \\
6 firms & $(0.74)$ & $(-0.56)$ & $(-1.09)$ & $(0.10)$ & $(-0.04)$ & $(0.07)$ & $(0.09)$ \\
\hline Fourth Quarter & $-0.10 \%$ & $-0.20 \%$ & $-0.41 \%$ & $-0.25 \%$ & $0.27 \%$ & $0.32 \%$ & $-0.34 \%$ \\
3 firms & $(-0.87)$ & $(-0.52)$ & $(-2.76)$ & $(-0.82)$ & $(0.20)$ & $(0.20)$ & $(-0.39)$ \\
\hline Firm Had & $0.20 \%$ & $0.67 \%$ & $0.14 \%$ & $0.43 \%$ & $1.15 \%$ & $2.13 \%$ & $1.72 \%$ \\
Only One Ad & $(1.28)$ & $(0.84)$ & $(0.17)$ & $(1.31)$ & $(2.30)^{* *}$ & $(1.86) *$ & $(1.41)$ \\
11 firms & & & & & & & \\
\hline Firm Had & $0.09 \%$ & $0.69 \%$ & $0.78 \%$ & $0.68 \%$ & $1.04 \%$ & $0.97 \%$ & $1.50 \%$ \\
Multiple Ads & $(0.33)$ & $(1.37)$ & $(1.66)$ & $(1.01)$ & $(0.97)$ & $(0.95)$ & $(1.29)$ \\
13 firms & & & & & & & \\
\hline
\end{tabular}

Panel B: Difference Between The Means Tests

\begin{tabular}{|c|c|c|c|c|c|c|c|}
\hline Days & $\begin{array}{c}\text { Qtr 1 vs. } \\
\text { Qtr 2 }\end{array}$ & $\begin{array}{c}\text { Qtr 1 vs. } \\
\text { Qtr 3 }\end{array}$ & $\begin{array}{c}\text { Qtr 1 vs. } \\
\text { Qtr 4 }\end{array}$ & $\begin{array}{c}\text { Qtr 2 vs. } \\
\text { Qtr 3 }\end{array}$ & $\begin{array}{c}\text { Qtr 2 vs. } \\
\text { Qtr 4 }\end{array}$ & $\begin{array}{c}\text { Qtr 3 vs. } \\
\text { Qtr 4 }\end{array}$ & $\begin{array}{c}\text { More } \\
\text { Than 1 Ad } \\
\text { Vs. } \\
\text { Only 1 Ad }\end{array}$ \\
\hline$(+1)$ & $(0.30)$ & $(-0.17)$ & $(0.59)$ & $(-.41)$ & $(0.28)$ & $(0.69)$ & $(-0.35)$ \\
\hline$(+1,+3)$ & $-(2.16)^{*}$ & $(0.91)$ & $(0.60)$ & $(2.34)^{* *}$ & $(1.80)$ & $(-0.21)$ & $(0.18)$ \\
\hline$(-1,+1)$ & $(0.81)$ & $(1.14)$ & $(1.18)$ & $(0.28)$ & $(0.52)$ & $(0.30)$ & $(0.32)$ \\
\hline$(-3,+3)$ & $(-1.35)^{* *}$ & $(0.60)$ & $(0.33)$ & $(2.03)^{*}$ & $(1.37)$ & $(-0.15)$ & $(-0.76)$ \\
\hline$(-4,+4)$ & $(-0.82)^{*}$ & $(0.77)$ & $(0.75)$ & $(1.70)$ & $(1.58)$ & $(0.23)$ & $(-0.13)$ \\
\hline
\end{tabular}

*significant at $.10 * *$ significant at $.05 * * *$ significant at .01

\section{Cross Section Regression Results}

The last analysis involves a cross section regression. Three different CARs windows are tested as shown in Table 5. The second and the third equation are both significant and the second equation explains over $30 \%$. Only one ad rating variable is used in each equation due to multicollinearity. The coefficient for the size of the firm is positive in all the equations and significant in one of the equations, thus, the larger the firm, the higher the CARs. It is interesting to note that the more ads that a firm had, the lower the returns, although the coefficient is never significant. The coefficient for QTR is negative and generally significant. This reflects the earlier findings that the ads from the second quarter had the highest returns.

The results for the ranking variables also confirm those results found with the univariate tests, although the Ad Age recall ranking was discarded since that only included two firms. The coefficient for USARANK is positive and always significant. Since the higher the number, the lower the ranking of the ad, this implies that higher rated ads had lower CARs. ADLIKE had a similar impact in that the higher the ranking, the lower the CARs. The coefficient for TIVO is negative which means that the ads that were Tivoed had lower CARs. Similarly, the coefficient for TOPTEN is negative: the higher the overall rankings for a firm's ads, the lower the CARs. While the last two coefficients are not significant, they do show consistent results with the other two ranking variables. 


\section{Table 5: Cross Section Regression}

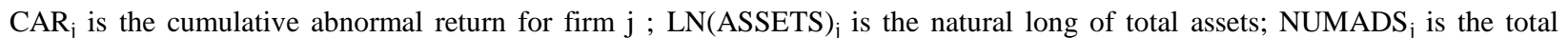
number of Super Bowl ads placed by each firm; QTR $_{\mathrm{j}}$ is the first quarter that any ad by a firm was shown; USARANK is the highest ranking of any of a firm's Superbowl ads as measured by the USA TODAY rating; ADLIKE $_{\mathrm{j}}$ is the ADVERTISING AGE rating for the top ten liked ads and is equal to the rank of the ad if in the top ten, and 11 otherwise; ADRECALL $_{\mathrm{j}}$ is the ADVERTISING AGE rating for the top ten recalled ads and is equal to the rank of the ad if in the top ten, and 11 otherwise; $\mathrm{TIVO}_{\mathrm{j}}$ is a dichotomous variable equal to 1 if the ad was in the top ten ads that were Tivoed, or else 0 ; TOPTEN $\mathrm{T}_{\mathrm{j}}$ is equal to the number of times a firm's ads were included in the top ten of any of the previous categories and if none of a firm's ads were in the top ten, then the variable is set equal to 0 . The $t$ statistics are shown in parenthesis and $*$ denotes significance.

\begin{tabular}{|c|c|c|c|c|c|c|}
\hline CARs & $(+1,+3)$ & $(-3,+3)$ & $(-4,+4)$ & $(-3,+3)$ & $(-3,+3)$ & $(-3,+3)$ \\
\hline CONSTANT & $\begin{array}{c}-0.0384 \\
(-0.73)\end{array}$ & $\begin{array}{l}-0.117 \\
(-1.49)\end{array}$ & $\begin{array}{c}-0.160 \\
(-1.74)^{*}\end{array}$ & $\begin{array}{c}-0.0786 \\
(-0.90)\end{array}$ & $\begin{array}{c}-0.0265 \\
(-0.29)\end{array}$ & $\begin{array}{l}-0.0308 \\
(-0.33)\end{array}$ \\
\hline LN(ASSETS) & $\begin{array}{c}0.0022 \\
(0.96)\end{array}$ & $\begin{array}{c}0.0054 \\
(1.61)\end{array}$ & $\begin{array}{l}0.0078 \\
(1.98)^{*}\end{array}$ & $\begin{array}{c}0.0028 \\
(0.74)\end{array}$ & $\begin{array}{c}0.0034 \\
(0.84)\end{array}$ & $\begin{array}{c}0.0031 \\
(0.77)\end{array}$ \\
\hline NUMADS & $\begin{array}{c}-0.0020 \\
(-0.72)\end{array}$ & $\begin{array}{c}-0.0022 \\
(-0.52)\end{array}$ & $\begin{array}{c}-0.0019 \\
(-0.39)\end{array}$ & & & \\
\hline QTR & $\begin{array}{l}-0.0082 \\
(-1.74)^{*}\end{array}$ & $\begin{array}{l}-0.0136 \\
(-1.93)^{*}\end{array}$ & $\begin{array}{c}-0.0173 \\
(-2.11)^{* *}\end{array}$ & $\begin{array}{c}-0.0124 \\
(-1.69)\end{array}$ & $\begin{array}{c}-0.0144 \\
(-1.52)\end{array}$ & $\begin{array}{r}-0.0104 \\
(-1.30)\end{array}$ \\
\hline USARANK & $\begin{array}{l}0.0005 \\
(2.05)^{*}\end{array}$ & $\begin{array}{c}.0013 \\
(3.17)^{* * *}\end{array}$ & $\begin{array}{l}0.0011 \\
(2.33)^{*} \\
\end{array}$ & & & \\
\hline ADLIKE & & & & $\begin{array}{c}0.0057 \\
(2.44)^{* *}\end{array}$ & & \\
\hline \multicolumn{7}{|l|}{ ADRECALL } \\
\hline TIVO & & & & & $\begin{array}{c}-0.0328 \\
(-1.46)\end{array}$ & \\
\hline TOPTEN & & & & & & $\begin{array}{r}-0.0034 \\
(-1.50)\end{array}$ \\
\hline ADJ RSQ & .162 & .344 & .245 & .145 & -.003 & .003 \\
\hline $\mathbf{F}$ & 2.11 & $4.02 * *$ & $2.86^{*}$ & 2.30 & 0.980 & 1.026 \\
\hline
\end{tabular}

*significant at $.10 * *$ significant at $.05 * * *$ significant at .01

\section{DISCUSSION}

Overall, our results do find significant positive returns for the three windows $(-2,+2),(-3,+3)$, and $(-4,+4)$ which indicates a positive impact of Super Bowl advertising before and after the game. This short-term, positive, impact is suggested by others in the literature including Fehle et al. (2005), in looking at Super Bowl ads from 1969 to 2001 and Chong et al. (2007), in looking at Super Bowl ads from 1990 to 2005, and Chang et al. (2005) in looking at Super Bowl ads from 1985 to 2002. This result though does differ from Filbeck et al. (2009) who overall found negative returns in looking at a summary of Super Bowl ads from 1990 to 2006 as well as Kim and Morris (2003), in looking at Super Bowl ad returns from 1998 to 2000, who found an immediate negative return, particularly for dot.com firms,

In terms of relating liking the ad with stock results, we find that while for the the USA TODAY rankings, the more highly rated do have higher returns the day after the Super Bowl, the difference is not significant. Surprisingly, those firms that are most highly rated, have significantly lower returns for the two day post Super Bowl window and the $(-3,+3)$ and $(-4,+4)$ windows. The liked rankings for Ad Age has similar results for both the first day and the longer windows with the first day returns being significantly higher while the longer windows are significantly lower. The top groupings for both the TIVO variable and the TOPTEN variable have significantly higher returns for the shorter $(-1,+1)$ window but the longer windows are once again negative although the differences are not significant. These results suggest that while there may be a positive immediate impact for higher rated ads, this impact is not statistically significant and does not last. The literature in terms of this finding is mixed as Filbeck et al. (2009) found firms with more creative campaigns were better received and Chang et al. (2009) found liked commercials coincided with higher stock returns, but Kim and Morris (2003) did not. Thus, while firms strive to make top scores in the USA Today Ad Meter, our results suggest this is not critical for financial success. 
This is somewhat similar to the finding of Srinivasan et al. (2009) in looking at the stock impact of innovations, who found that while perceptions of quality significantly impacted stock price, perceptions of customer liking, did not. Delattre (2007) notes the need for testing the influence of marketing variables in measuring stock price impact.

In terms of the quarter in which firms had ads, those firms whose ads were first shown in the second quarter perform better than any other quarter. This suggests that the second quarter should be the first choice for Super Bowl advertisers. Also, firms that had only one ad perform better the first day following the Super Bowl and for the longer windows, although the differences are not significant. Kim and Morris (2003) also did not find a significant relationship between number of ads and stock price, while Filbeck et al. (2009) and Chang et al. (2005) find that firms spending a greater percentage of advertising dollars tend to have more positive stock impacts.

It is vital that marketers can model the economic linkage between marketing actions, expected cash flows, and shareholders wealth; marketers need to demonstrate the increasing productivity of their actions, their impact on a firm's competitive posture and, thus, on a firm's long-term viability (Rao and Bharadwaj, 2008). One reason why Super Bowl advertising in particular may be attractive for investors is that individual investors prefer to invest in stocks with easily recognized products and thus, greater information precisions (Frieder and Subrahmanyam, 2005). While the Super Bowl is the most expensive advertising event, it does represent the largest audience for advertisers (Advertising Age, 2007). This is important given the decrease in television audience (estimated to be 2.5 million fewer viewers this year versus last) (Bauder, 2007). Thus, Super Bowl television advertising is still a sure way for marketers to reach a large audience, but given the huge expenditure, marketers need to be able to maximize the impact of their advertising as well as demonstrate the financial effectiveness of it. Our study makes a contribution to the literature by illustrating the impact of Super Bowl advertising.

\section{Limitations And Future Research}

The results of this study intend to provoke further research and discussion. Due to the small number of firms that do advertise in the Super Bowl, future research needs to examine trends over a period of several years before generalizations can be made. Additionally, in looking at the literature, there is not a consistent pattern of effect of Super Bowl advertising, stressing the need for additional research in this area to determine what criteria are needed for most success in terms of Super Bowl advertising. For example, Kim, McMillan, and Hwang (2005) examine the type of advertising strategies and use of integrated marketing communications in Super Bowl advertising. Future research could utilize event study methodology to compare results across different advertising approaches and integrations. Research is also needed to determine if the Super Bowl makes more financial sense for some product categories (such as beer, snacks, and soft drinks) than others (such as cosmetics) (Neff, 2007). Additionally, given our results that there was not a positive significant relationship between liking Super Bowl ads (as measured by USA Today, Advertising Age, and TIVO) and stock price, event study methodology needs to be compared with traditional measures of advertising success, such as brand awareness, long-term recall and brand attitudes. Finally, the impact of Super Bowl advertising combined with other methods such as the Internet should be ascertained as the combination may be more effective than either method alone.

\section{CONCLUSION}

Advertisers are under significant pressure to demonstrate the financial return for the investment of advertising. For the year studied, the 2007 Super Bowl ads were seen as overall "unusually good as effective advertising" (Garfield, 2007). Our results support that somewhat. While advertising in the Super Bowl does not have a significant positive impact on a firm's stock price the day after the Super Bowl, when considering windows from two to four days before and after there is a significant positive stock price effect. This suggests that there is an impact, but that firms need to utilize both pre and post publicity and other media to maximize that impact. However, we find that the means advertisers use to judge the effectiveness of Super Bowl advertising (i.e. likability) has no significant relationship with financial effectiveness as measured by stock price. This suggests that the means marketers use to judge Super Bowl advertising effectiveness may not be good measures of business success in financial terms. Our results also suggest that if a firm does choose to advertise in the Super Bowl, they may want to pick the second quarter for their ad. Finally, advertisers need to maximize pre-Super Bowl publicity as the media does discuss the ads before they run. Finally, Srinivasan et al. (2009) offer that advertising for support for 
innovations have significantly positive impacts on stock prices. Based on this finding, we would recommend that firms with product innovations utilize Super Bowl advertising. In general, future research and discussion is needed to best determine how firms can effectively utilize Super Bowl advertising and how marketers can utilize a variety of measures to determine the effectiveness of advertising.

\section{AUTHOR INFORMATION}

Jacqueline K. Eastman (Ph.D, Florida State University) is an Associate Professor of Marketing at Georgia Southern University. She has published in journals including Journal of Academy of Marketing Science, Journal of Business Research, Journal of Business Ethics, Journal of Advertising, Journal of Marketing Theory and Practice, Journal of Consumer Marketing, and Marketing Management Journal among others.

Rajesh Iyer (Ph.D., Southern Illinois University at Carbondale) is an Assistant Professor of Marketing at Bradley University. His research interests include services marketing, advertising and branding issues, and scales research. He has published in journals including Journal of Marketing Theory and Practice, Journal of Consumer Marketing, and Marketing Management Journal among others.

Joan Wiggenhorn (Ph.D., Florida Atlantic University) is an Associate Professor of Finance at Florida Institute of Technology. She has published in various finance and economic journals, as well as journals in international business. The journals include Quarterly Review of Economics and Finance, Journal of Economics and Finance, International Journal of Managerial Finance, and Journal of World Business.

\section{REFERENCES}

1. Advertising Age. (2007, February 5), "Super Bowl 2007, Advertising History: 40 Years of Prices and Audience," http://adage.com/SuperBowlBuyers/superbowlhistory07.html.

2. Agarwal, J. and Wagner A. K. (1995), "The Economic Worth of Celebrity Endorsers: An Event Study Analysis." Journal of Marketing 59, 3, 56-62.

3. Atkinson, C. (2007, January 29), "Measuring Bowl ROI? Good Luck," Advertising Age, http://adage.com/print?article id=114590.

4. Bauder, D. (2007, May 8), "Data Says 2.5 Million Less Watching TV," Comcast Entertainment News, http://www.comcast.net/entertainment/index.jsp?cat=ENTERTAINMENT\&fn=/2007/05/08/657892.html.

5. $\quad$ Brown, S. J. And J. B. Warner (1985), “Using Daily Stock Returns: The Case of Event Studies.” Journal of Financial Economics 14, 3-31.

6. Cacioppo, J. T., and R. E. Petty (1979), "Effects of Message Repetition and Position on Cognitive Response, Recall and Persuasion." Journal of Personality and Social Psychology 37, 1, 97-109.

7. $\quad$ CBS Sportsline (2007), "SuperAds." http://www.cbs.sportsline.com/nfl/postseason/superads (accessed February 21).

8. Chaney. P. K., T. M. Devinney, and R. S. Winer (1991), "The Impact of New Product Introductions on the Market Value of Firms." Journal of Business 64, 4, 573-610.

9. Chang, C., J. Jiang, and K. A. Kim (2009), "A Test of the Representativeness Bias Effect on Stock Prices: A Study of Super Bowl Commercial Likeability," Economics Letters, 103, 49-51.

10. Chong, P., G. Filbeck, D. L. Tompkins, and T. D. Ashman (2002), "Targeting the Ad Bowl: Is It a Super Strategy," Proceedings of the Allied Academies International Conference, 7 (2), 15-20.

11. Chong, P., G. Filbeck, D.L. Tompkins (2007), "Advertising Strategy and Returns on Advertising: A Market Value Approach," The Business Review, 8, 2 (December), 17-23.

12. Clancy, K. J. and P. C. Krieg (2006, May/June), "Fact Finder: Go Beyond Faith When Making Decisions About Sponsorships and Events." Marketing Management, 28-33.

13. Clark, J.M., T.B. Cornwell, and S.W. Pruitt (2009), "The Impact of Title Event Sponsorship Announcements on Shareholder Wealth," Marketing Letters, 20, 169-182.

14. Cox, D. and D. Peterson (1994), "Stock returns following large one-day declines: Evidence on short-term reversals and longer-term performance." Journal of Finance 49, 255-267.

15. Creamer, M. and J. Mullman (2007, March 5). "Why A-B Is King of 'USA Today's' Puffed-Up Poll," Advertising Age http://adage.com/print?article_id=115347. 
16. Cuneo, A. Z. (2007a, January 29), “HP Super Bowl Strategy to Stoke Sales,” Advertising Age. http://adage.com/print?article id=114605.

17. Cuneo, A. Z. (2007b, February 5), "Marketers Turn to Mobile to Stretch Their Super Bowl Buys," Advertising Age, http://adage.com/print?article_id=114671.

18. Delattre, Eric. 2007. "Event study methodology in marketing” Recherche et applications en Marketing, 22,2,57-75.

19. Fehle, F., S. Tsyplakov, and V. Zdorovtsov (2005), "Can Companies Influence Investor Behaviour through Advertising? Super Bowl Commercials and Stock Returns,” European Financial Management 11 (5), 625647.

20. Filbeck, G., X. Zhao, D. Tompkins, and P. Chong (2009), "Share Price Reactions to Advertising Announcements and Broadcast of Media Events," Managerial and Decision Economics, 30, 253-264.

21. Frieder, L. and A. Subrahmanyam (2005, March), "Brand Perceptions and the Market for Common Stock," Journal of Financial and Quantitative Analysis, 40 (1), 57-85.

22. Garfield, B. (2007, February 5), "Bob Garfield Reviews the Super Bowl Commercials," Advertising Age http://adage.com/print?article id=114655.

23. Horovitz, B. (2007, February 5), "Budweiser Wins With Crabby Crawlers As Anheuser-Busch Takes Seven of Top 10," USA Today, http://www.usatoday.com/money/advertising/admeter/2007-02-04-admeter-winners x.htm.

24. Johnson, J. and G.J. Tellis (2005, Fall), "Blowing Bubbles: Heuristics and Biases in the Run-Up of Stock Prices," Journal of the Academy of Marketing Science, 33 (4), 486-503.

25. Johnston, M.A. (2007), "A Review of the Application of Event Studies in Marketing," Academy of Marketing Science Review, 4, 1-31.

26. Johnston, M.A. (2010), "The Impact of Sponsorship Announcements on Shareholder Wealth in Australia," Asia Pacific Journal of Marketing and Logistics, 22 (2), 156-178.

27. Jones, E.A.E. and J. Danbolt (2005), "Empirical Evidence on the Determinants of the Stock Market Reaction to Product and Market Diversification Announcements," Applied Financial Economics, 15, 623629.

28. Kim, J., and J. D. Morris (2003, September). "The effect of Advertising on the Market Value of the firms: Empirical Evidence from the Super Bowl ads." Journal of Targeting, Measurement \& Analysis for Marketing, 12, 53-65.

29. Kim, J., S. J. McMillan, and J-S. Hwang (2005, Fall), "Strategies for the Super Bowl of Advertising: An Analysis of How the Web is Integrated into Campaigns," Journal of Interactive Advertising, 6 (1), 59-78.

30. Lane, V. and R. Jacobson (1995), "Stock Market Reactions to brand Extension Announcements: The effects of Brand Attitude and Familiarity." Journal of Marketing 59, 1, 63-77.

31. Mathur, L.K., I. Mathur, and N. Rangan (1997, May-June), "The Wealth Effects Associated with a Celebrity Endorser: The Michael Jordan Phenomenon," Journal of Advertising Research, 67-73.

32. McAlister, L., R. Srinivasan, and M. Kim (2007, January), “Advertising, Research and Development, and Systematic Risk of the Firm," Journal of Marketing, 71, 35-48.

33. Miyazaki, D. A. and A. G. Morgan. (2001, January/February), “Assessing Market Value of Event Sponsoring: Corporate Olympic Sponsorships.” Journal of Advertising Research, 9-15.

34. Mullman, J. (2007a, February 5), “A-B Shows Off Its Super Bowl Creative,” Advertising Age. http://adage.com/print?article_id=114687.

35. Mullman, J. (2007b, March 8), "CareerBuilder in Review After Messy Split With C-K," Advertising Age http://adage.com/print?article_id=115444.

36. Neff, J. (2007, January 29), "P\&G, Unilever Sit Out the Super Bowl," Advertising Age, http://adage.com/print?article $\mathrm{id}=114588$.

37. Oler, D., Harrison, J. and M. Allen (2008) “The Danger of Misinterpreting Short-Window Event Study Findings in Strategic Management Research: An Empirical Illustration Using Horizontal Acquisitions”, Strategic Organization, 6,2, 151-184.

38. Rauch, M. (2001, January) “Does Superbowl Marketing Pay Off?,” Sales \& Marketing Management, 153 (1), p. 20.

39. Rao, R.K.S, and N. Bharadwaj (2008, January), "Marketing Initiatives, Expected Cash Flows, and Shareholders' Wealth," Journal of Marketing, 72, 16-26. 
40. Spais, G.S. and G.N. Filis (2006), "Stock Market Reaction on Olympic Sponsorship Announcement using Event Study Method," Journal of Korean Academy of Marketing Science, 16, 95-108

41. Spais, G.S. and G.N. Filis (2008), "Measuring Stock Market Reaction to Sponsorship Announcements: The Case of Fiat and Juventus," Journal of Targeting, Measurement and Analysis for Marketing, 16 (3), 169-180.

42. Srinivasan, S. and D. M. Hanssens (2009, June), "Marketing and Firm Value: Metrics, Methods, Findings, and Future Directions," Journal of Marketing Research, XLVI, 293-312.

43. Srinivasan, S., K. Pauwels, J. Silva-Risso, and D.M. Hanssens (2009, January), "Product Innovations, Advertising, and Stock Returns," Journal of Marketing, 73, 23-43.

44. Steinberg, B. (2007, January 12), "Super Bowl Advertisers Hand Amateurs the Ball," The Wall Street Journal Online. http://online.wsj.com/article_email/SB1168568062778747021MyQjAxMDE3NjE4ODUxNjg4Wj.html.

45. Tellis, G., and K. Tellis, (2009)"Research on Advertising in a Recession," Journal of Advertising Research, 49, 3, 304-327.

46. Tsai, D., S. Chang, and W. Chen (2005), "Economic Worth of Advertising Campaigns: Evidence of Advertising During the Super Bowl," American Academy of Advertising Conference Proceedings, 144.

47. Thompson,S. (2007, January 31), "Phillips-Van Heusen Buys Its First Super Bowl Ad," Advertising Age http://adage.com/print?article id=114652.

48. Wiggenhorn, J., Eastman, J., Iyer,R. and K. Armul (Forthcoming), "The Market Effect of Super Bowl Advertising During a Recession, Journal of Business and Economic Perspectives.

49. WU, B. and S. Newell (2003), "Evaluating the Impact of Advertisement Characteristics on Recall During the Super Bowl: A Two Year Comparison." Marketing Management Journal 13, 2, 122-128. 